\title{
The Effect of High Temperature on the Growth Performance of Hybrid Tilapia Oreochromis niloticus $X$ Oreochromis aureus Juveniles Reared in a Recycling System
}

\author{
Ana Laura Ibáñez ${ }^{1^{*}}$, Tanahiri Torres-Vázquez ${ }^{1}$ \\ and Sergio Humberto Álvarez-Hernández ${ }^{1}$ \\ ${ }^{1}$ Departamento de Hidrobiología, Universidad Autónoma Metropolitana-Iztapalapa, Av. San Rafael \\ Atlixco 186, Col. Vicentina, D.F. 09340, Ciudad de México, México.
}

Authors' contributions

This work was carried out in collaboration among all authors. Authors ALI and SHAH designed the study, wrote the protocol and wrote the first draft of the manuscript. Authors ALI, SHAH and TTV managed the analyses of the study, performed the statistical analysis and managed the literature searches. All authors read and approved the final manuscript.

Article Information

DOI: $10.9734 / A R R B / 2019 / v 32 i 130073$

Editor(s):

(1) Dr. Paola Angelini, Department of Applied Biology, University of Perugia, Perugia, Italy. (2) Dr. George Perry, Dean and Professor of Biology, University of Texas at San Antonio, USA.

Reviewers:

(1) Mohamed EL Sayed Megahed, National Institute of Oceanography and Fisheries (NIOF), Egypt.

(2) Felix Eze, Nigeria Maritime University, Nigeria.

Complete Peer review History: http://www.sdiarticle3.com/review-history/49642

Short Research Article

Received 30 March 2019

Accepted 11 June 2019

Published 17 June 2019

\section{ABSTRACT}

Tilapia juveniles live in littoral regions of freshwater ecosystems which have temperatures that may reach critical values for growth, especially in face of the onslaught of climate change. This study analyzes the effect of temperature $\left(25,30,35,40^{\circ} \mathrm{C}\right)$ on the growth and survival of hybrid tilapia juveniles in a re-circulating system. Duplicate groups of 30 juveniles were stocked in $200 \mathrm{~L}$ tanks in a closed, re-circulating system. Automatic heaters were used to establish the water temperatures, commercial food was supplied at $5 \%$ of their weight as daily ration. Fish were weighed and measured at 15-day intervals for a period of 3 months. Water temperature and dissolved oxygen were monitored daily. Ammonia, nitrates and dissolved reactive phosphorus were monitored every third day. Fish responses were estimated through variations in length, weight and inter-circuli space 
of fish scales. Average initial and final weight and length, Specific growth rate (SGR), Fulton Index $(\mathrm{FI})$, Length-weight relationship and survival were used to assess tilapia growth performance. Weight, length, SGR and FI were significantly affected $(P<0.05)$ by water temperature. Growth of the fish reared at $30^{\circ} \mathrm{C}$ was almost one third greater than that at $25^{\circ} \mathrm{C}$ and one sixth greater than that at $35^{\circ} \mathrm{C}$. Except for fish reared at $40^{\circ} \mathrm{C}$, the other treatments showed a positive allometric growth, with the better results recorded for the 30 and $35^{\circ} \mathrm{C}$ treatments. The fish reared at $40^{\circ} \mathrm{C}$ survived only two weeks while the survival rate of 98,90 and $88.3 \%$ for 25,30 and $35^{\circ} \mathrm{C}$, respectively.

Keywords: Tilapia; growth; climate change; temperature; cichlids; tilapia hybrids.

\section{INTRODUCTION}

Cichlids tend to live in lentic aquatic system and are good at hiding on swamp banks. These littoral areas, regularly inhabited by juveniles, have temperatures that may reach critical values for growth, especially in face of the onslaught of climate change when continental aquatic environments may experience increases in temperature that could exceed the high tolerance degree of many species. Both experimental and field studies have reported an optimum temperature range (for reproduction, growth and survival) for the tilapia Oreochromis niloticus (Linnaeus, 1758) of 25 to $32^{\circ} \mathrm{C}$, with the greater survival and the optimal metabolic rate recorded at $28^{\circ} \mathrm{C}[1,2]$. Tilapia tolerate temperatures up to $40^{\circ} \mathrm{C}$ [3], though this temperature induces stress, disease and mortality. The best growth of $O$. niloticus juveniles was recorded at 26 and $30^{\circ} \mathrm{C}$ [4]. Young O. niloticus preferred temperatures of 30 to $36^{\circ} \mathrm{C}$, while a temperature of around $41^{\circ} \mathrm{C}$ was lethal [5]. Likewise, [6] reported $100 \%$ mortality at $39^{\circ} \mathrm{C}$, high survival rates at $33^{\circ} \mathrm{C}$, the best growth at 27 to $35^{\circ} \mathrm{C}$, and an optimum temperature of $27^{\circ} \mathrm{C}$.

Organisms belonging to the same species that possess strains, such as many fish, present differential physiological responses [7]. Cold tolerance of tilapia species and hybrids have showed that the genetic variation have a large dominance component [8] and that even different stocks of tilapia show very different temperature tolerances [9]. However, for tilapia hybrids there are actually few studies on temperature tolerance $[10,8,11,9]$ and it is also necessary to study the effect cause under various conditions, such as extreme temperature in case of future climate change that induced temperature rise.

This study was therefore designed to analyze the effect of different temperatures $\left(25,30,35,40^{\circ} \mathrm{C}\right)$ on the growth performance and survival rate of hybrid tilapia juveniles (Oreochormis niloticus $\mathrm{x}$
O. aureus) in a re-circulating system, considering the increase in water temperature along the littoral zone fringe of freshwater dams.

\section{METHODOLOGY}

This study was carried out at the indoor Fish Biology wet laboratory of the Autonomous Metropolitan University, Campus Iztapalapa, in Mexico City. Nile tilapia juveniles were obtained from the "Rubio" fish farm in Morelos State. The specimens were homogenous in size and body weight, and visibly healthy. They were fed the same diet for one week prior to introducing them to the experimental conditions. Duplicate groups of 30 juveniles $(1.9 \pm 0.45 \mathrm{~g}$ and $4.8 \pm 0.32 \mathrm{~cm}$ average initial weight and length respectively) were stocked in $200 \mathrm{~L}$ plastic tanks in a closed, re-circulating system where each tank was independent and received a separate treatment system. Automatic heaters with thermostats were used to establish the four water temperatures $\left(25,30,35,40^{\circ} \mathrm{C}\right)$ to which the fish were subjected. Each tank was provided with aeration through an air compressor (Fluval mod MS306). A commercial diet with $32 \%$ crude protein was provided (Nutripec brand) at a daily rate of $5 \%$ of the body weight in two rations. The fish were weighed and measured at 15-day intervals (in order to obtain growth changes and do not stress the fish juveniles), and their daily ration was readjusted accordingly to size.

Water temperature (measured with a mercury thermometer) and dissolved oxygen (measured with HI947 HANNA Oxygen meter) were monitored daily. Ammonia, nitrates and dissolved reactive phosphorus (measured with $\mathrm{HI} 83203$ HANNA Photometer) were monitored every third day. Fish responses to different temperatures were estimated through variations in length, weight and inter-circuli spaces in order to test if inter-circuli distances are a good indicator of growth. An inverted microscope Invertoscop-D, Karl Zeiss, was used to make the inter-circuli 
distances using a micrometric eyepiece $\mathrm{Kpl}$ W8x/20, calibrated with a micrometric push bar of $1 \mathrm{~mm}$ with 100 subdivisions $(0.01 \mathrm{~mm}$ each division). The last four external inter-circuli spaces were measured (from the focus of the scale at an angle of $45^{\circ}$ ), considered these as indicators of the last environmental conditions. Four scales were sampled at the initial and final stages. The subsequent parameters were used to assess tilapia growth performance such as: Average initial and final weight and length, Specific growth rate SGR $=100 \times(\mathrm{Ln} W f-L n$ Wi)/t, Fulton Index $\mathrm{K}=100 \times\left(\mathrm{W} / \mathrm{Lt}^{3}\right)$ and Lengthweight relationship $W_{t}=a L^{b}$, where: $W_{f}=$ Final wet weight, $W_{i}=$ Initial wet weight, $L_{t}=$ Final total length, $L t_{i}=$ Initial total length, $t=$ Time interval in days, $a$ and $b=$ parameters of the allometric ratio between Total weight $\left(\mathrm{W}_{\mathrm{t}}\right)$ and Total length $\left(L_{t}\right)$, and $L n=$ the Napierian logarithm. Also, a $t$-test $(\alpha=0.05)$ was carried out to test the slope between temperature treatments, where $t_{b}$ was the $t$-value for the null hypothesis $b=3$. Survival rate was also estimated. Due to a filter failure, specimens in the $30^{\circ} \mathrm{C}$ tank suffered high mortality two weeks before the end of the experiment, for which reason a maximum likelihood EM method was used [12] and six data were recovered; SPSS ver. 15 was used for this analysis.

In order to justify a parametric analysis, a Mauchly's Test of Sphericity was carried out. However, as the data did not reach the condition of sphericity $[13,14]$, a mixed model ANOVA was calculated with weight and length data. In order to calculate differences between averages, a Bonferroni post hoc test was applied. All tests were performed with SPSS Ver. 15.

Mauchly's sphericity test rejected the $\mathrm{H}_{0}\left(\mathrm{H}_{\mathrm{o}}=\right.$ the sphericity assumption was fulfilled). Due to this, an ANOVA for repeated measures was applied. No differences were obtained for the two replicates $(P>0.05)$. At the beginning, no significant differences were recorded for the length and weight values. Finally, a regression analysis for temperature versus mean size was run.

\section{RESULTS}

The results indicated that weight, length, SGR and Fulton Index were significantly affected ( $p<$ $0.05)$ by water temperature. The growth of the fish reared at $30^{\circ} \mathrm{C}$ was almost one third greater than that at $25^{\circ} \mathrm{C}$ and one sixth greater than that at $35^{\circ} \mathrm{C}$ (Table 1). Except for the fish reared at $40^{\circ} \mathrm{C}$, the other treatments showed a positive allometric growth, with the better results recorded for the 30 and $35^{\circ} \mathrm{C}$ treatments (Table 1). Fish length obtained at $30^{\circ} \mathrm{C}$ was greater throughout the experiment, followed by that obtained at $35^{\circ} \mathrm{C}$ (Fig. 1).

The best growth was obtained at $30^{\circ} \mathrm{C}$ and was significantly different from that obtained at 25 and $35^{\circ} \mathrm{C}(p<0.05)$, whereas the least growth was obtained at $40^{\circ} \mathrm{C}(\mathrm{P}<0.05)$. Fish survival ranged between $0 \%$ and $95 \%$ and was significantly different $(P<0.05)$. The fish reared at $40^{\circ} \mathrm{C}$ survived only two weeks, while the low survival recorded at $30^{\circ} \mathrm{C}$ was caused by a failure in the filter system two weeks before finishing the experiment.

A quadratic effect $(P<0.01)$ was recorded for temperature versus mean size (Fig. 2), where $31^{\circ} \mathrm{C}$ was the optimum temperature for the species, probably because they were not stressed at 25 and $30^{\circ} \mathrm{C}$, while the fish in the $35^{\circ} \mathrm{C}$ treatment showed red eyes and had a softer skin. Fish at $40^{\circ} \mathrm{C}$ lived only two weeks, hardly ate, were very stressed, and presented red eyes, very smooth skin and blood spills (Fig. 3a). Distension of the belly was also observed (Fig. 3b).

Table 1. Effects of water temperature on initial and final weight (Mean \pm SE), Species growth rate (SGR); Fulton Index, $b$ parameter of length-weight relationship and survival (\%) of tilapia hybrid juveniles

\begin{tabular}{lllllll}
\hline $\begin{array}{l}\text { Temperature } \\
{ }^{\circ} \mathbf{C}\end{array}$ & $\begin{array}{l}\mathbf{W}_{\mathbf{i}} \\
\mathbf{( g )}\end{array}$ & $\begin{array}{l}\mathbf{W}_{\mathbf{f}} \\
\mathbf{( g )}\end{array}$ & $\begin{array}{l}\text { SGR } \\
(\mathbf{\%} / \text { day) }\end{array}$ & $\begin{array}{l}\text { Fulton } \\
\text { Index }\end{array}$ & $\boldsymbol{b}$ & $\begin{array}{l}\text { Survival } \\
(\%)\end{array}$ \\
\hline 25 & $1.91 \pm 0.52$ & $31.61 \pm 8.53$ & 3.34 & 1.69 & $3.07(+)$ & 95.0 \\
30 & $1.91 \pm 0.51$ & $53.24 \pm 13.88$ & 3.96 & 1.87 & $3.14(+)$ & $43\left(90^{*}\right)$ \\
35 & $1.97 \pm 0.34$ & $44.71 \pm 10.78$ & 3.71 & 1.80 & $3.14(+)$ & 88.3 \\
40 & $1.95 \pm 0.40$ & $2.22 \pm 0.32$ & 0.14 & 1.67 & $2.72(-)$ & 0 \\
\hline
\end{tabular}

$W_{i}=$ Average initial weight; $W_{f}=$ Average final weight; SGR, species growth rate; Fulton Index.

*In parenthesis is the survival estimation for specimens in $30^{\circ} \mathrm{C}$ treatment if mortality wasn't operated by a filter failure 


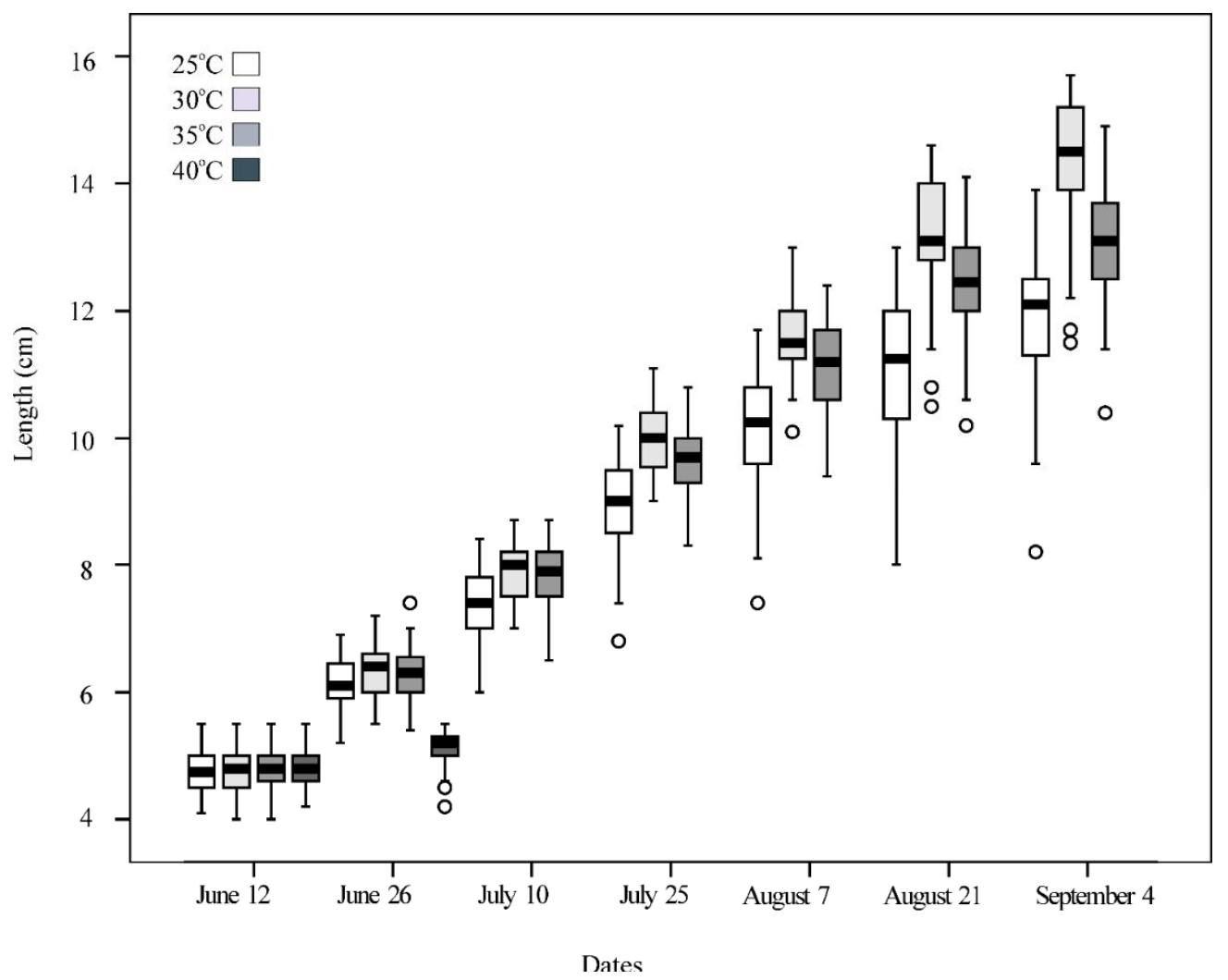

Fig. 1. Boxplot depicting size $(\mathrm{cm})$ of Oreochromis niloticus $X O$. aureus for the treatments $25^{\circ} \mathrm{C}, 30^{\circ} \mathrm{C}, 35^{\circ} \mathrm{C}$ and $40^{\circ} \mathrm{C}$ along the seven dates measured

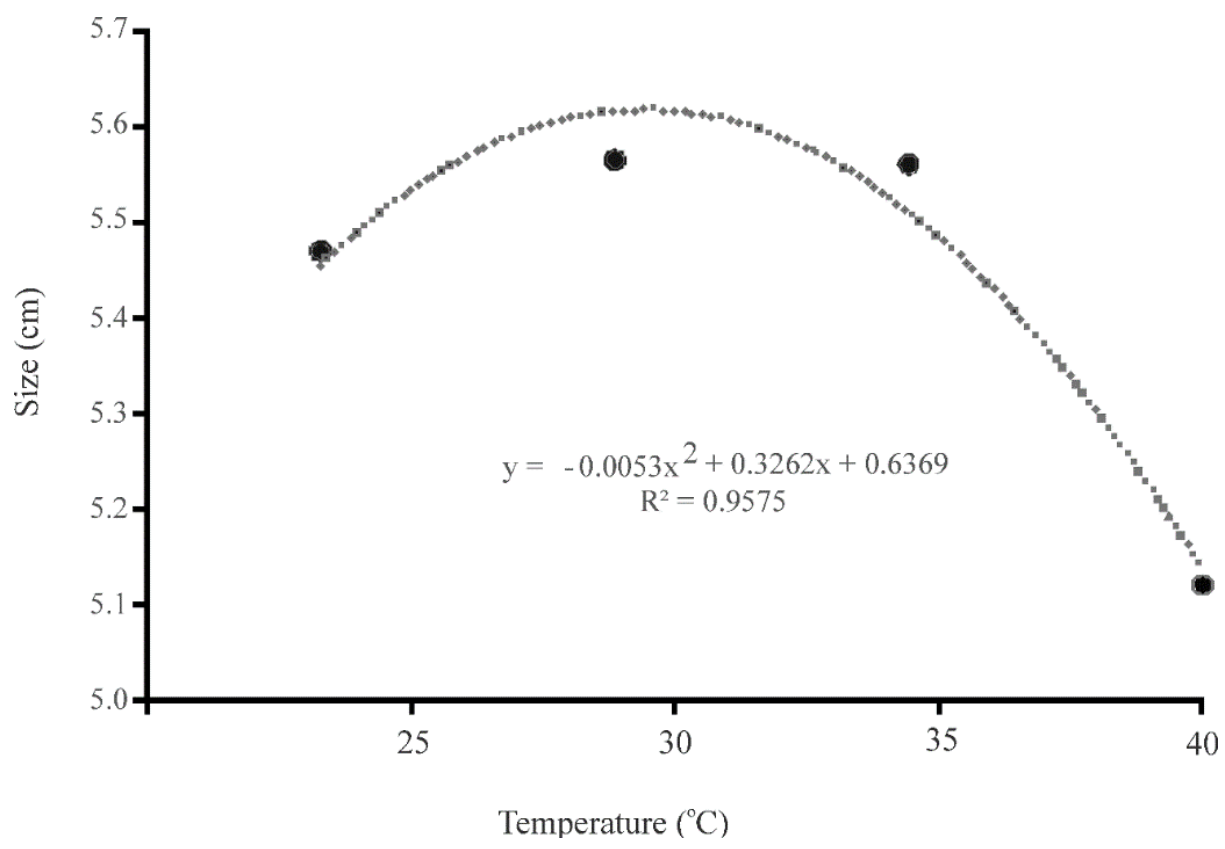

Fig. 2. Quadratic relationship $(P<0.01)$ between temperature and mean size 


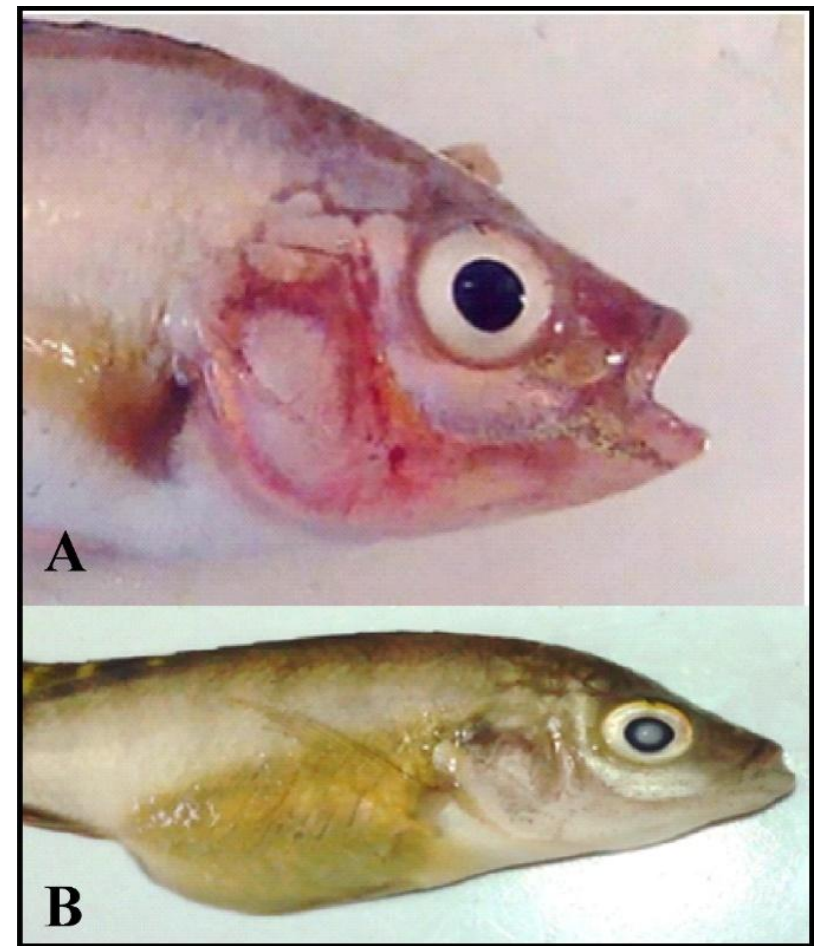

Fig. 3. A. Oreochromis niloticus $X O$. aureus juveniles of treatment $40^{\circ} \mathrm{C}$ after fifteen days. Red eyes very smooth skin and spills blood; B. Belly distension and spleen and pancreas sickness

Minimum and maximum values of dissolved oxygen were 3.2 and $7.4 \mathrm{mg} / \mathrm{L}$. Average values of ammonia ranged from 0.4 to $0.7 \mathrm{mg} / \mathrm{L}$. Average values of nitrates and dissolved reactive phosphorus ranged from 0.19 to 7.1 , and 1.2 to $6.3 \mathrm{mg} / \mathrm{L}$ respectively. No significant differences in the parameters were observed among treatments $(P>0.05)$.

The initial value for the inter-circuli distance was $35.05 \pm 0.0008 \mu \mathrm{m}$, with no significant differences between treatments. The final value did show significant differences $(P<0.05)$ between the $30^{\circ} \mathrm{C}$ treatment $(80.18 \pm 0.007 \mu \mathrm{m})$ and the 25 and $35^{\circ} \mathrm{C}$ treatments $(51.80 \pm$ $0.00095 \mu \mathrm{m}$ and $62.70 \pm 0.000029 \mu \mathrm{m}$ respectively).

\section{DISCUSSION}

The present study verified that rearing Nile tilapia juveniles at the optimum water temperature $\left(30^{\circ} \mathrm{C}\right)$ results in a significant improvement in growth performance. However, fish growth rates and survival were significantly reduced at 25 and $35^{\circ} \mathrm{C}$. The length-weight relationship was not a good parameter to separate well-being since only the fish reared at $40^{\circ} \mathrm{C}$ showed differences in growth performance. In most species of fish, the exponent $b$ is close to 3 , but this index may change due to strong variations in temperature or through starvation $[15,16]$. Fish reared at $40^{\circ} \mathrm{C}$ hardly ate and no growth was observed during the 15 days they survived. As was observed in this study, [17] mentioned that $O$. niloticus reared at $37^{\circ} \mathrm{C}$ had a reduced survival and a low food intake. [18] reported $25^{\circ} \mathrm{C}$ as the optimum temperature for nutrient digestibility in the tilapia O. niloticus. Nevertheless, it has been mentioned that a greater temperature increases the rate of passing digesta through the intestinal tract, reducing the digestibility and assimilation of nutrients [19]. Therefore, the reduction in growth performance at $35^{\circ} \mathrm{C}$ could be attributed to a high rate of gastric evacuation. As in this study, [4] recorded a maximum $O$. niloticus fry growth at $30^{\circ} \mathrm{C}$ in relation to a maximum feed consumption, and also reported that hightemperature (almost $37^{\circ} \mathrm{C}$ ) treatments yielded a significantly higher proportion of males with lower survival rates. This masculinization effect at high temperatures should be considered in the aquaculture industry, although most aquaculture takes place in waters that are not thermoregulated and undergo more or less pronounced daily variations [20]. It is also important to 
mention that the temperature used in cultures influences the growth of different tilapia strains [21]. According to [9], the Oreochromis mossambicus $\mathrm{x}$ Wami Tilapia O. urolepis hybrid from aquaculture was most tolerant to higher temperatures $\left(33-38^{\circ} \mathrm{C}\right)$, while the Blue Tilapia $O$. aureus was the most tolerant to colder temperatures $\left(11-16^{\circ} \mathrm{C}\right)$. Regarding the importance of water temperature observed in tilapia growth [22,4,20,1], behavioral factors produce a slower growth of small specimens and a resulting greater size dispersal.

The inter-circuli space was useful to compare growth rates, as the inter-circuli space of the scales and growth are related [23]. The range of dissolved oxygen values was suitable for Nile tilapia feeding and growth, this in agreement with [24]. Ammonia tolerance ranges for tilapia of 0.001 to $0.2 \mathrm{mg} / \mathrm{L}$ were reported by [25] and of 0.35 to $0.5 \mathrm{mg} / \mathrm{L}$ by [26]. Wicki [27] reported nitrate tolerance values at concentrations of up to $100 \mathrm{mg} / \mathrm{L}$, and dissolved reactive phosphorus tolerance values of 0.6 to $1.5 \mathrm{mg} / \mathrm{L}$ [28]. Water quality was not within the recommended values or the tolerance range of the species, particularly in the case of ammonia and dissolved reactive phosphorus. However, since high values were recorded for all the treatments, the quality of the water was not considered to have an effect on the results or to be an additional stressor.

According to [29], several tropical dams located at 17 and $18^{\circ}$ North latitude have surface temperatures of 30 to $35^{\circ} \mathrm{C}$ (Caracol Dam: up to $30^{\circ} \mathrm{C}$ during March-July, Nezahualcoyotl Dam: $28-30^{\circ} \mathrm{C}$, Aguamilpas Dam: $24-35^{\circ} \mathrm{C}$ ), and some dams located at $27^{\circ}$ North latitude may have temperatures above $30^{\circ} \mathrm{C}$ during the summer days. In agreement with the [30], global temperature will increase 2 to $6^{\circ} \mathrm{C}$ this century. However, the temperature of aquatic systems in many regions could reach greater temperatures sooner than expected during the summers, and global warming scenarios could affect the survival and growth of shallow-water species and lead to the extinction of the affected species. The strain Oreochromis niloticus $\mathrm{X}$ Oreochromis aureus tolerates temperatures above $30^{\circ} \mathrm{C}$ as was recorded in this study, but it does not survive at $40^{\circ} \mathrm{C}$.

\section{CONCLUSIONS}

We can conclude that the better growth for Oreochromis niloticus $X O$. aureus was for $30^{\circ} \mathrm{C}$ followed by $35^{\circ} \mathrm{C}$ treatments while the juveniles reared at $40^{\circ} \mathrm{C}$ survived only two weeks and almost no growth was recorded during that time.

\section{COMPETING INTERESTS}

Authors have declared that no competing interests exist.

\section{REFERENCES}

1. El-Sayed AFM, Kawanna M. Optimum water temperature boosts the growth performance of Nile tilapia (Oreochromis niloticus) fry reared in a recycling system. Aquac Res. 2008;39:670-672.

DOI: 10.1111/j.1365-2109.2008.01915.x

2. Nal-Asgah N, Ali A. Growth performance and body composition of Oreochromis niloticus reared at different water temperatures. Ann Zootechnie. 1997; 46:331-338.

Available:https://hal.archivesouvertes.fr/hal-00889699/document

3. Popma TJ, Lovshin LL. Worldwide prospects for commercial production of tilapia. In: Research and Development series No. 41. International Center for Aquatic Environments. Department of Fisheries and Allied Aquacultures, Auburn University, Alabama; 1996.

4. Azaza MS, Dhraïef MN, Kraïem MM. Effects of water temperature on growth and sex ratio of juvenile Nile tilapia Oreochromis niloticus (Linnaeus) reared in geothermal waters in southern Tunisia. $J$ Therm Biol. 2008;33:98-105.

DOI: 10.1016/j.jtherbio.2007.05.007

5. Guma'a SA, Salih A. Use of a minifluviarium to study responses of young Sarotherodon niloticus $(\mathrm{L})$ to hydrogen-ion concentrations and temperature. Hydrobiologia. 1986;135: 243-250.

6. Baras E, Jacobs B, Mélard C. Effect of water temperature on survival, growth and phenotypic sex of mixed (XX-XY) progenies of Nile tilapia Oreochromis niloticus. Aquaculture. 2001;192:187-199. doi.org/10.1016/S0044-8486(00)00452-X

7. Álvarez-Hernández S, De-Lara-Isassi G, Arredondo-Figureroa JL, CamposVerduzco R. Segregación de las variedades roja y Stirling de Oreochromis niloticus (Piscis:Cichlidae) mediante la 
lectina algal "Giraffina". Hidrobiológica. 2001;11(2): 117-121. Spanish.

8. Cnaani A, Gall GAE, Hulata G. Cold tolerance of tilapia species and hybrids. Aquac Int. 2000;8(4):289-298.

DOI: 10.1023/A:1009299109614

9. Lorenzi V, Schlenk D. Impacts of Combined Salinity and Temperature Extremes on Different Strains and Species of Tilapia Inhabiting the Watershed of the Salton Sea. N Am J Aquac. 2014;76(3): 211-221.

DOI: $10.1080 / 15222055.2014 .893471$

10. Soderberg RW. Temperature effects on the growth of blue tilapia in intensive aquaculture. N Am Aquac. 1990;52(3): 155-157.

DOI: $10.1577 / 1548-8640(1990) 052<0155$ : TEOTGO>2.3.CO;2

11. Sardella BA, Cooper J, Gonzalez RJ, Brauner CJ. The effect of temperature on juvenile Mozambique tilapia hybrids (Oreochromis mossambicus x O-urolepis homorum) exposed to full-strength and hypersaline seawater. Comparative Biochemistry and Physiology a-molecular \& Integrative Physiology. 2004;137(4): 621-629.

DOI: 10.1016/j.cbpb.2003.12.003

12. Dempster AP, Laird NM, Rubin DB. Maximum likelihood estimation from incomplete data via the EM algorithm. Appl Stat. 1977;39(1):1-38.

Available:https://www.jstor.org/stable/2984 875

13. Huynh H, Feldt LS. Conditions under which mean square ratios in repeated measurement designs have exact $F$ distribution. J Am Stat Assoc. 1970;65: 1582-1589.

DOI: 10.1080/01621459.1970.10481187

14. Rouanet $H$, Lepine D. Comparison between treatments in a repeated measures design: Anova and multivariate methods. Br J Math Stat Psychol. 1970; 23:147-163.

15. Froese R. Cube law, condition factor and weight-length relationships: history, metaanalysis and recommendations. J Appl Ichthyol. 2006;22:241-253.

16. Martin WR. The mechanics of environmental control of body form in fishes. Ontario Fisheries Research Laboratory. 1949;58:1-91.
17. Pandit NP, Nakamura M. Efecto de la alta temperatura sobre la supervivencia, el crecimiento y la tasa de conversión alimenticia de tilapia del Nilo, Oreochromis niloticus. Nuestra Naturaleza. 2010;8:219224. Spanish.

18. Watanabe T, Takeuchi T, Satoh S, Kiron $\mathrm{V}$. Digestible crude protein contents in various feedstuffs determined with four freshwater fish species. Fish Sci. 1996;62: 278-282.

DOI: $10.2331 /$ fishsci.62.278

19. Elliot JM. Rates of gastric evacuation in brown trout, Salmo trutta (L.). Freshw Biol. 1972;2:1-18. doi.org/10.1111/j.13652427.1972.tb01575.x

20. Azaza MS, Legendre M, Kraiem MM, Baras E. Size-dependent effects of daily thermal fluctuations on the growth and size heterogeneity of Nile tilapia Oreochromis niloticus. J Fish Biol. 2010;76:669-683. DOI: 10.1111/j.1095-8649.2009.02524.x.

21. dos Santos VB, Mareco EA, Silva MDP. Growth curves of Nile tilapia (Oreochromis niloticus) strains cultivated at different temperatures. Acta Sci. 2013;35:235-242. doi.org/10.4025/actascianimsci.v35i3.1944 3

22. Atwood HL, Tomasso JR, Webb H, Gatlin DM. Low-temperature tolerance of Nile tilapia, Oreochromis niloticus; effects of environmental and dietary factors. Aquaculture Research. 2003;34:241-251. doi.org/10.1046/j.13652109.2003.00811.x

23. Ibáñez $A L$, Castellanos $M$, Rodríguez $A$, Álvarez-Hernández S. Influencia de la temperatura, densidad, oxígeno y alimento en la formación de marcas en las escamas de tilapia. Rev Biol Trop. 2017; 65:613622. Spanish. doi.org/10.15517/rbt.v65i2.25897

24. Xu JY, Miao XW, Lu Y, Cui SR. Behavioral response of tilapia (Oreochromis niloticus) to acute ammonia stress monitored by computer vision. J Zhejiang Univ Sci B. 2005;6:812-816.

DOI: 10.1631/jzus.2005.B0812

25. El-Sayed AFM. Tilapia culture. Cabi Publishing Oxfordshire UK; 2006.

26. Williams K. Tilapia culture in cages and open ponds. Langston University Agricultural Research and Extension Programs; 2000. 
Available:http://www2.luresext.edu/ aquaculture/tilapia\%20culture.htm

27. Wicki GA. Estudio de desarrollo y producción de tilapia (Oreochromis niloticus). Secretaria de Agricultura, Pesca y Alimentación. Subsecretaria de Pesca: Buenos Aires Argentina; 1997. Spanish.

28. Nicovita. Manual de crianza de tilapia. Nicovita ALICORP; 2007. Spanish.
Available:http://www.

nicovita.com.pe/paginas/esp/ tilapia.htm

29. De-la-Lanza G. Lagos y presas de México. Centro de Ecología y Desarrollo. México, DF; 1995. Spanish.

30. IPCC. Climate Change 2001: The Scientific Basis. Contribution of Working Group I to the Third Assessment Report of the Intergovernmental Panel on Climate Change. Houghton, J.T., Ding, D.J.; 2001.

(c) 2019 Ibáñez et al.; This is an Open Access article distributed under the terms of the Creative Commons Attribution License (http://creativecommons.org/licenses/by/4.0), which permits unrestricted use, distribution, and reproduction in any medium, provided the original work is properly cited.

Peer-review history:

The peer review history for this paper can be accessed here: http://www.sdiarticle3.com/review-history/49642 